\title{
Uniwersalia przekładowe
}

- ang. translation universals - termin wprowadzony przez Monę Baker w związku z jej hipotezą o istnieniu cech językowych występujących z zauważalnie większą częstotliwością w tekstach tłumaczonych niż w tekstach niebędących przekładami, przy czym cechy te nie wynikają z wpływu języka oryginału na język przekładu. Hipotezę tę sformułowała badaczka w artykule Corpus linguistics and translation studies - implications and applications z roku $1993 \mathrm{i}$ od tego czasu w studiach przekładowych (Translation Studies) toczy się nad nią żywa dyskusja.

Zagadnienie uniwersaliów pojawiło się z chwilą, gdy do deskryptywnych badań nad przekładem (Descriptive Translation Studies) wkroczyła lingwistyka korpusowa (corpus linguistics). Jest to rozwijająca się od lat siedemdziesiątych XX wieku gałąź językoznawstwa, której przedmiotem, materiałem i narzędziem stały się elektroniczne korpusy językowe - ogromne zbiory zdigitalizowanych tekstów (wypowiedzi językowych) lub ich próbek, dobranych wedle konkretnych kryteriów (np. zakres, forma, odniesienie temporalne) i wykorzystywanych za pomocą odpowiednich programów komputerowych do analizy różnych zjawisk językowych. Najbardziej znane, reprezentatywne i ogólnie dostępne w Internecie są powszechne korpusy języków narodowych oparte przeważnie na języku pisanym, choć istnieją również korpusy języka mówionego (transkrybowanego). Gromadzą one różne rodzaje tekstów: literackie, prasowe, naukowe, specjalistyczne itd., a oprócz zastosowania do badań naukowych są szeroko stosowane m.in. w praktyce pisarskiej, edytorskiej, dydaktycznej czy translatorskiej.

Dla tłumaczy oraz badaczy zjawisk przekładowych szczególnie użyteczne są korpusy porównawcze (comparable) i paralelne (parallel). Te ostatnie zawierają teksty źródłowe oraz ich przekłady na jeden lub więcej języków - ich starożytnym prototypem jest słynny kamień z Rosetty z 196 roku p.n.e., na którym ten sam tekst został zapisany w dwóch językach - egipskim i greckim - trzema rodzajami pisma: greką, demotyką i hieroglifami. Jak wiadomo, to właśnie dzięki niemu Jean-François Champollion rozwiązał zagadkę hieroglifów. Warto podkreślić, że obserwowany od stosunkowo niedawna skok jakościowy w możliwościach Google Translator i innych aplikacji translatorskich zawdzięczamy właśnie dynamicznemu rozwojowi takich korpusów. Natomiast korpusy porównawcze nie są zorientowane na tłumaczenia, ale zawierają teksty dające się porównywać ze względu na konkretne parametry, np. gatunek, tematykę, przedział czasowy itp.

W badaniach nastawionych na potwierdzenie lub podważenie tezy o istnieniu uniwersaliów przekładowych tworzy się i analizuje narzędziami stylometrycznymi korpusy zbudowane z par tekstów źródłowych i docelowych ${ }^{1}$ lub korpusy jednojęzyczne złożone z tekstów tłumaczonych oraz z tekstów niebędących tłumaczeniami. Metodologiczna kwestia zasad konstruowania korpusu do badań nad uniwersaliami (dobór tekstów, wielkość korpusu) pozostaje jedną z kluczowych i dyskusyjnych w tej materii.

\footnotetext{
${ }^{1}$ W Polsce takie badania prowadzi Jan Rybicki, zob. np. tegoż, Original, Translation, Inflation. Are All Translations Longer than Their Originals?, „Digital Humanities” 2010.
} 
Uniwersalia przekładowe zatem to - według najprostszej definicji - cechy typowe dla języka tekstów tłumaczonych, a nieumotywowane właściwościami oryginałów oraz danych systemów językowych ${ }^{2}$. Badacze popierający tezę o ich istnieniu często wolą mówić o tendencjach czy prawach zamiast o uniwersaliach, jako że nie sposób definitywnie wykazać ich powszechność, jednak analizy stylometryczne prowadzone na korpusach porównawczych rzeczywiście potwierdzają, iż coś takiego jak „styl przekładowy” da się z tego materiału językowego w skali makro wydobyć. Do miana uniwersaliów kandydują takie właściwości tłumaczeń, jak unikanie powtórzeń obecnych w tekście źródłowym (avoidance of repetitions present in the source text), symplifikacja (simplification), normalizacja (normalization), transfer dyskursu (discourse transfer), dystynktywna dystrybucja jednostek leksykalnych (distinctive distribution of lexical items) oraz - przyciągająca najwięcej uwagi badaczy przekładu - eksplicytacja (explicitation). Redukowanie powtórzeń jest np. nagminną praktyką w pracy tłumacza literatury pięknej z języka angielskiego na język polski, co widać zwłaszcza w przekładach dialogów, gdzie monotonne said zastępuje się takimi ekwiwalentami, jak „powiedział”, „rzekł”, „odparła”, „przytaknęła” itp. Tendencję tę wzmacniają dodatkowo ingerencje redaktorów wydawniczych i ewentualne poprawki sugerowane przez autorów tekstu źródłowego; na tym tle szczególnie rysuje się fenomen autoprzekładu, będącego w istocie drugą autorską redakcją utworu. Symplifikacja może przejawiać się m.in. w upraszczaniu składni, normalizacja zaś jest skutkiem dostosowywania języka tekstu tłumaczonego do norm języka docelowego (np. wbrew nienormatywnym cechom stylistyki oryginału) - badania stylometryczne wykazały, że oba te zabiegi szczególnie często występują w tłumaczeniu tekstów naukowych, a znacznie rzadziej w przekładach dzieł literackich. Transfer dyskursu wiąże się ze sformułowanym przez Gideona Toury'ego „prawem interferencji" (the law of interference) w przekładzie i polega na tym, że wypowiedź tłumaczona jest konstruowana bezpośrednio pod wpływem tekstu źródłowego, nie zaś w zgodności z normą języka docelowego. Zjawisko to można zaobserwować np. na poziomie składni, gdyż dość łatwo jest rozpoznać przekładowy charakter tekstu po tym właśnie, że zdania w języku docelowym zachowują, wskutek interferencji, cechy syntaktyczne zdań języka oryginału - co powszechnie uważa się za wadę tłumaczenia. Dystynktywna dystrybucja słów to zwiększona (i wskutek tego zauważalna) częstotliwość występowania w tekstach tłumaczeń określonych leksemów w stosunku do ich częstotliwości w odpowiednich tekstach źródłowych oraz w tekstach w języku docelowym niebędących tłumaczeniami.

Eksplicytacja natomiast to „transformacja polegająca na eksplicytnym wyrażeniu w tekście docelowym tego, co implicytne w tekście wyjściowym lub na bardziej eksplicytnym wyrażeniu tego, co już eksplicytne w oryginale. Innymi słowy, eksplicytacja ma miejsce, jeśli treści implikowane czy też presuponowane w tekście wyjściowym zostały wyrażone wprost w tekście docelowym lub jeśli element tekstu wyjściowego został uwydatniony w tekście przekładu przez zastosowanie emfazy lub dobór środków leksykalnych. Innym czynnikiem definiującym eksplicytację jest jej niezależność od różnic systemowych. [...] dowodem na istnienie eksplicytacji w tekście przekładu jest możliwość wypracowania jego poprawnej, lecz mniej eksplicytnej wersji”3. Przykładem takiej transformacji może być dokonany przez Bronisława Zielińskiego

\footnotetext{
${ }^{2}$ Routlege Encyclopaedia of Translation Studies, ed. M. Baker, wyd. 3, London-New York 2005, s. 288-291.

${ }^{3}$ E. Gumul, Explicitation in Simultaneous Interpreting. A Study into Explicitating Behaviour of Trainee Interpreters, Katowice 2017, s. 325.
} 
przekład znanej frazy Johna Donne'a "no man is an island” w cytacie wykorzystanym przez Ernesta Hemingwaya w powieści Komu bije dzwon (której tytuł został również zaczerpnięty z tego cytatu). Polski tłumacz nadał temu krótkiemu zdaniu następującą formę: „Żaden człowiek nie jest samoistną wyspą”, podczas gdy wersją pozbawioną eksplicytacji byłoby „nikt nie jest wyspą".

Eksplicytacja jest zatem bliska technice tłumaczeniowej zwanej nadtłumaczeniem (overtranslation), polegającej na dodawaniu (amplifikacji) pewnych informacji szczegółowych do tekstu przekładu. Nadtłumaczenie jest wszakże efektem świadomej i celowej decyzji tłumacza, dotyczącej konkretnych miejsc w tekście, podczas gdy eksplicytacja to wynik procesów kognitywnych zachodzących na poziomie nie w pełni uświadamianym i obejmujących całokształt działań translacyjnych. Sytuuje się zatem, wedle określenia Andrew Chestermana, „poza tym, co szczegółowe" (beyond the particular) ${ }^{4} \mathrm{i}$ właśnie dlatego przez zwolenników tezy Mony Baker jest uważana za sztandarowy przykład uniwersaliów przekładowych.

\section{Ewa Kraskowska}

\footnotetext{
${ }^{4}$ A. Chesterman, Beyond the particular, [w:] Translation Universals. Do they exist?, ed. A. Mauranen, P. Kujamäkki, Amsterdam-Philadelphia 2004, s. 33-50.
} 


\title{
SEOWA KLUCZOWE:
}

e k s plicyta c ja

\begin{abstract}
ABSTRAKT:
Artykuł przedstawia zagadnienie tzw. uniwersaliów przekładowych, które pojawiło się w związku z rozwojem lingwistyki korpusowej. Wysunięta przez Monę Baker hipoteza o istnieniu takich uniwersaliów wywołuje kontrowersje wśród badaczy zjawisk przekładowych, co również zostało w artykule pokrótce zreferowane.
\end{abstract}

\section{NOTA O AUTORZE:}

Ewa Kraskowska - prof. zw. w Instytucie Filologii Polskiej Uniwersytetu im. Adama Mickiewicza w Poznaniu, literaturoznawczyni, badaczka pisarstwa kobiet oraz problemów przekładu literackiego. Kierowniczka Zakładu Literatury XX Wieku, Teorii Literatury i Sztuki Przekładu. Ostatnio pod jej redakcją ukazała się monografia zbiorowa Polskie pisarstwo kobiet $w$ wielu XX: procesy i gatunki, sytuacje i tematy (Poznań 2015). 